\title{
PENGELOLAAN DANA DESA DI DESA ABBUMPUNGENG KECAMATAN CINA KABUPATEN BONE
}

\author{
Fenny Fausia $^{1}$, Abdul Kadir Adys ${ }^{2}$, Adnan Ma'ruf ${ }^{3}$ \\ ${ }^{1}$ Mahasiswa Program Studi Ilmu Administrasi Negara Fisip Unismuh \\ ${ }^{2}$ Dosen Program Studi Ilmu Administrasi Negara Fisip Unismuh \\ ${ }^{3}$ Dosen Program Studi Ilmu Administrasi Negara Fisip Unismuh
}

\begin{abstract}
This study purposed to find out how the management of village funds at the Abbumpungeng Village, Cina District, Bone Regency. The number of informants in this study were 8 people. This study used qualitative research with descriptive type. Data collection techniques were observatuon, interviews and documentation. The results of the study showed that the management of village funds in Abbumpungeng village, Cina District, Bone Regency had been quite good but not yet effective and efficient. This could be seen from the aspects of planning, implementation and supervision that had not been carried out optimally because from the planning stage there had not yet been a musdus, then from its implementation it was still often constrained by the slow disbursement of village funds resulting in delayed development and in terms of supervision because it was not transparent information board in the village office. But only on the organizing aspect that had beeb implemented quite well because it invilved the community in the village development process.
\end{abstract}

Keywords : Management, Village Funds

\begin{abstract}
ABSTRAK
Tujuan penelitian ini yaitu untuk mengetahui bagaimana pengelolaan dana Desa di Desa Abbumpungeng Kecamatan Cina Kabupaten Bone. Jumlah informan dalam penelitian ini adalah 8 orang. Jenis penelitian ini menggunakan jenis penelitian kualitatif dengan tipe deskriptif. Teknik pengumpulan data menggunakan metode observasi, wawancara dan dokumentasi. Hasil penelitian menunjukkan bahwa pengelolaan dana desa di desa Abbumpungeng, kecamatan Cina, kabupaten Bone sudah cukup baik namun belum cukup efektif dan efisien. Hal ini terlihat dari aspek perencanaan, pelaksanaan dan pengawasan yang belum cukup dilaksanakan dengan optimal, karena dari tahap perencanaan belum mengadakan musdus, kemudian dari pelaksanaannya masih sering terkendala oleh lambatnya pencairan dana desa yang mengakibatkan tertundanya pembangunan serta dari segi pengawasan karena belum transparan, terlihat dari tidak adanya papan informasi di kantor desa tersebut. Hanya pada aspek pengorganisasian yang sudah terlaksana dengan cukup baik karena melibatkan masyarakat dalam proses pembangunan desa.
\end{abstract}

Kata Kunci : Pengelolaan, Dana Desa 
Kolaborasi : Jurnal Administrasi Publik, April 2020 Volume 6 Nomor 1

\section{PENDAHULUAN}

Pemerintah Desa adalah penyelenggara urusan pemerintahan oleh Pemerintah Desa dan Badan Permusyawaratan Desa dalam menjalankan dan mengawasi kepentingan masyarakat berdasarkan asal-usul dan adat istiadat yang diakui dalam Pemerintahan Negara Republik Indonesia. Sedangkan pemerintahan desa adalah Kepala Desa serta Perangkat Desa sebagai unsur penyelenggaraan pemerintahan Desa. Dalam penyelenggaraan pemerintahan Desa, salah satu tugas Kepala Desa yaitu mengelola dana Desa dimana dana Desa merupakan dana yang berasal dari Anggaran Pendapatan dan Belanja Negara yang diberikan bagi Desa dan ditransfer melalui Anggaran Pendapatan dan Belanja Daerah Kabupaten/Kota kemudian digunakan guna membiayai penyelenggaraan pemerintahan, pelakasanaan pembangunan, pembinaan kemasyarakatan dan pemberdayaan masyarakat.

UU No. 6 Tahun 2014 Tentang Desa pasal 72 menyatakan bahwa pendapatan desa yang berasal dari APBN, atau dana desa, bersumber dari belanja pusat dengan mengoptimalisasikan program yang berbasis desa secara merata dan efektif. Dana Desa diberikan oleh pemerintah untuk Desa. Agar dana Desa yang dapat digunakan untuk membangun infrastruktur Desa sesuai dengan ketentuan yang ditetapkan dan untuk itu, maka diperlukan pengelolaan dana Desa dengan baik. Dengan adanya dana Desa menjadikan sumber pemasukan disetiap Desa akan meningkat. Meningkatnya pendapatan desa yang diberikan oleh pemerintah untuk meningkatkan taraf hidup masyarakat Desa

Pengelolaan dana Desa atau dapat disebut manajemen dana desa merupakan suatu rangkaian proses mengatur dan mengarahkan penggunaan dana Desa dalam hal memenuhi kepentingan pemerintahan Desa juga dalam hal mensejahteraan masyarakat Desa agar terarah dan efektif serta efisien dalam penggunaan dana Desa.

Secara etimologi, manajemen berasal dari bahasa Prancis kuno, yaitu management yang artinya seni mengatur dan melaksanakan. 
Kolaborasi : Jurnal Administrasi Publik, April 2020 Volume 6 Nomor 1

Manajemen dapat juga didefinisikan sebagai proses atau rangkaian pekerjaan yang melibatkan pengarahan sekelompok orang dalam suatu organisasi menuju kearah tujuan-tujuan organisasional. Manajemen yaitu suatu bentuk kegiatan perencanaan, pengorganisasian, pelaksanaan dan pengawasan. (Kasmir, 2006). Pengelolaan berarti juga Manajemen, yang berarti pengaturan atau pengurusan (Suharsimi Arikunto 1993:31).

Ada tiga alasan utama manajemen sangat dibutuhkan menurut T. Hani Handoko (Richard, 2002) yaitu: a) Manajemen diperlukan dalam menjaga keseimbangan antara tujuan, kegiatan, dan sasaran yang saling bertolak belakang dari pihak yang memiliki kepentingan dalam organisasi, b) Manajemen juga diperlukan untuk mencapai efisien dan efektifitas suatu kerja organisasi, c) Serta manajemen juga sangat diperlukan dalam pencapaian tujuan pribadi dan organisasi.

Menurut Mary Parker Follet (Richard, 2002), pengertian manajemen adalah sebuah seni dalam mengarahkan orang lain dalam menyelesaikan pekerjaannya. Artinya, seorang manajer memiliki peran mengarahkan serta mengatur orang lain demi tercapainya tujuan organisasi.

Menurut Thomas (Thomas, 2013) manajemen atau pengelolaan yaitu suatu proses atau suatu rangkaian pekerjaan yang dilakukan oleh serangkaian kelompok orang didalamnya terdapat perencanaan, pengorganisasian, pelaksanaan dan pengawasan dengan memanfaatkan potensi yang ada dalam mencapai tujuan tertentu.

Menurut Terry (Terry dan Rue, 2010), manajemen yaitu sebuah proses yang terdiri dari beberapa tindakan yaitu perencanaan, pengorganisasian, pelaksanaan serta pengawasan. Semua itu dilakukan guna menentukan dalam pencapaian target atau sasaran yang ingin dicapai dengan memanfaatkan semua sumber daya, termasuk sumber daya manusia dan sumber daya lainnya.

Menurut Henry Fayol (Rahmat, 2017), manajemen merupakan rangkaian kegiatan perencanaan, pengorganisasian, pengkoordinasian, serta pengawasan terhadap sumber 
Kolaborasi : Jurnal Administrasi Publik, April 2020 Volume 6 Nomor 1

daya yang ada agar mencapai tujuan yang efektif dan efisien.

Fungsi-fungsi Manajemen Menurut George R. Terry (Terry dan Rue, 2010): 1. Perencanaan (planning), yaitu awal dari segala sesuatu yang akan dikerjakan dalam mencapai tujuan, pemikiran serta penyusunan langkah-langkah apa yang akan dipakai dalam mencapai tujuan. Merencanakan artinya merancang seluruh kebutuhan, memperhitungkan apa saja kekurangan dan kelebihan, serta menentukan apa saja pelaksanaan kegiatan yang dimaksudkan dalam pencapaian tujuan.

2. Pengorganisasian (organization), yaitu pembagian atau pengumpulan orang-orang dan menempatkan mereka sesuai kemampuan serta keahliannya dalam suatu pekerjaan yang telah direncanakan. 3 . Penggerakan (actuating), yaitu pelaksanaan kegiatan organisasi yang telah mendapatkan pembagian kerja serta menggerakan seluruh sumber daya yang ada dalam organisasi agar kegiatan yang dilakukan berjalan sesuai rencana dan dapat mencapai tujuan. 4. Pengawasan (controlling), yaitu untuk mengawasi apakah kegiatan yang dilakukan oleh organisasi tersebut sesuai dengan rencana atau sebaliknya. Serta segala sumber daya yang ada di dalam organisasi tersebut diawasi agar tepat guna serta terpakai dengan efektif dan efisien.

Berdasarkan pendapat diatas, maka dapat disimpulkan bahwa menurut Terry (Terry dan Rue, 2010) bahwa dalam pengelolaan terdapat empat indikator yaitu perencanaan dimana pada indikator pertama ini ditetapkan rencana awal dalam pencapaian tujuan, kemudian pengorganisasian yaitu pembagian kerja dalam pengelolaan, lalu pelaksanaan apabila telah dibagikan pekerjaan maka indikator selanjutnya yaitu pelaksanaan pekerjaan tersebut, dan yang terakhir yaitu pengawasan dimana pada tahap ini dilakukan pengawasan dalam pelaksanaan pekerjaan tersebut dalam pencapaian tujuan suatu organisasi.

Berdasarkan pendapat Fayol (Rahmat, 2017), maka dapat disimpulkan bahwa pengelolaan memiliki lima indikator yaitu perencanaan, pengorganisasian, penyusunan personalia atau penem- 
Kolaborasi : Jurnal Administrasi Publik, April 2020 Volume 6 Nomor 1

patan seorang karyawan sesuai dengan kemampuannya, serta pengarahan yaitu membimbing karyawan dalam melaksanakan tugasnya dengan baik, dan yang terakhir yaitu pengawasan dari beberapa indikator diatas agar pengelolaan berjalan sesuai apa yang direncanakan serta dapat mencapai tujuan.

Undang-Undang RI Nomor 6 Tahun 2014 mengenai Desa, definisi Desa yaitu kesatuan masyarakat hukum yang memiliki batas wilayah dan berwenang untuk mengatur semua urusan pemerintahan serta kepentingan masyarakat setempat berdasarkan asal-usul, prakarsa masyarakat, dan hak tradisional yang diakui serta dihormati dalam sistem pemerintah Negara Kesatuan Republik Indonesia.

Pemerintah Desa merupakan tempat tinggal masyarakat yang paling dasar yang terdiri dari beberapa dusun dan memiliki batas wilayah serta dipimpin oleh kepala desa yang dipilih melalui pemilihan kepala desa. Dalam unsur pemerintahan desa selain kepala desa terdapat juga Perangkat Desa serta Badan
Permusyawaratan Desa (BPD) dalam penyelenggara pemerintahan desa.

Pembangunan desa menurut Rondinelli (Yusran Lapanada 2016:42) merupakan pemanfaatan hasil pembangunan fisik desa yaitu dengan membangun atau memperbaiki prasarana jalan desa akan menciptakan atau memperbaiki kehidupan masyarakat desa. Menurut Siagian (2008:31), pembangunan adalah suatu usaha atau rangkaian usaha pertumbuhan dan perubahan yang terencana yang dilakukan secara sadar oleh suatu bangsa, negara dan pemerintah menuju modernitas dalam rangka pembinaan bangsa (nation building).

Badan Permusyawaratan Desa atau yang disingkat BPD, yaitu suatu lembaga dalam penyelenggaraan pemerintahan Desa yang diperuntukkan dalam pelaksanaan pemerintahan Desa (Peraturan Pemerintah No 72 tahun 2005).

Peraturan desa ditetapkan oleh kepala desa bersama BPD. Peraturan desa dibentuk dalam rangka penyelenggaraan pemerintahan desa. Peraturan desa merupakan penjabaran lebih kanjut dari 
Kolaborasi : Jurnal Administrasi Publik, April 2020 Volume 6 Nomor 1

peraturan perundang-undangan yang lebih tinggi dengan memperhatikan kondisi social budaya masyarakat desa setempat.

Dana Desa yaitu dana yang berasal dari APBN dan diperuntukkan guna membiayai pelaksanaan pembangunan, pemberdayaan masyarakat, serta pemerintahan. Pada awalnya dana Desa ini dimaksudkan untuk mengganti PNPM yang merupakan program pemerintah.

Pembangunan desa menurut Rondinelli (Yusran Lapanada 2016:42) merupakan pemanfaatan hasil pembangunan fisik desa yaitu dengan membangun atau memperbaiki prasarana jalan desa akan menciptakan atau memperbaiki kehidupan masyarakat desa.

Berdasarkan UU Nomor 6 Tahun 2014 tentang Desa, bahwa pemerintah menyalurkan dana Desa. Berdasarkan hal tersebut, maka tiap Kabupaten/kota menyalurkan kepada setiap Desa dengan memperhitungkan luas wilayah sebanyak 20\%, jumlah penduduk sebanyak $30 \%$ serta tingkat kemiskinan sebanyak 50\%. Hasil perhitungan tersebut juga disesuaikan dengan letak geografis Desa.

Berdasarkan Peraturan Pemerintah No. 60 Tahun 2014 tentang Dana Desa Yang berasal dari APBN, lingkup kewenangan Desa yang luas serta dalam rangka mengoptimalisasikan penggunaan dana Desa, maka prioritas penggunaan dana Desa yaitu untuk pembangunan serta pemberdayaan masyarakat Desa.

Dana desa merupakan dana yang diberikan kepada kepala Desa untuk membiayai berlangsungnya penyelenggaraan pemerintahan, pembangunan dan pemberdayaan masyarakat Desa agar tercipta kesejahteraan masyarakat. Dana Desa ditransfer oleh Kabupaten/Kota kepada setiap Desa.

BPD atau Badan Permusyawaratan Desa yaitu suatu lembaga yang berfungsi untuk melaksanakan pemerintahan yang anggotanya merupakan wakil penduduk Desa serta masyarakat yang melakukan kegiatan musyawarah yang dilaksanakan oleh BPD guna menyepakati hal-hal yang bersifat strategis.

Anggaran belanja dan pendapatan desa adalah rencana 
Kolaborasi : Jurnal Administrasi Publik, April 2020 Volume 6 Nomor 1

keuangan desa dalam satu tahun yang memuat perkiraan pendapatan, rencana belanja program dan kegiatan, dan rencana pembiayaan yang dibahas dan disetujui bersama oleh pemerintah desa dan badan permusyawaratan desa dan ditetapkan dengan peraturan desa. Penyelenggaraan pemerintahan desa yang output-nya berupa pelayanan public, pembangunan, dan perlindungan masyarakat harus disusun perencanaannya setiap tahun dan dituangkan dalam APBDesa. Dalam APBDesa inilah terlihat apa yang akan dikerjakan pemerintah desa dalam tahun berjalan.

Pemerintah desa wajib membuat APBDesa. Melalui APBDesa kebijakan desa yang dijabarkan dalam berbagai program dan kegiatan sudah ditentukan anggarannya. Dengan demikian, kegiatan pemerintah desa berupa pemberian pelayanan, pembangunan, dan perlindungan kepada warga dalam tahun berjalan sudah dirancang anggarannya sehingga sudah dipastikan dapat dilaksanakan. Tanpa APBDesa, pemerintah desa tidak dapat melaksanakan program dan kegiatan pelayanan publik.

\section{METODE PENELITIAN}

Penelitian ini dilakukan di Desa Abbumpungeng, Kecamat Cina, Kabupaten Bone selama kurang lebih 2 bulan dengan menggunakan jenis penelitian kualitatif dengan tipe penelitian deskriptif, data primer dalam penelitian ini adalah sumber data yang diperoleh langsung dari hasil wawancara serta melakukan observasi mengenai pengelolaan dana desa di desa Abbumpungeng kecamatan Cina Kabupaten Bone. Adapun informan dalam penelitian ini yaitu sekertaris desa, Kepala kesejahteraan dan pelayanan, kepala Dusun Lerang I, kepala dusun Lerang II. Kepala dusun Pattiro Data, kepala dusun Lomping serta masyarakat. Pengumpulan data melalui wawancara, observasi dan dokumentasi. Dalam menganalisis data menggunakan reduksi data, penyajian data dan penarikan kesimpulan. Sedangkan untuk pengabsahan data menggunakan triangulasi sumber, triangulasi 
Kolaborasi : Jurnal Administrasi Publik, April 2020 Volume 6 Nomor 1

teknik dan triangulasi waktu (Sugiono, 2016).

\section{HASIL DAN PEMBAHASAN}

Luas Desa Abbumpungeng sekitar 5,8 KM sebagian besar lahan di desa Abbumpungeng digunakan sebagai tempat tinggal, lokasi kantor pemerintahan daerah, sawah dan tempat perniagaan dan usaha. Ada juga sebagian kecil penduduk yang berkebun dan beternak

Batas wilayah desa Abbumpungeng dari sebelah Timur yaitu Desa Arasoe, sebelah Utara Desa Cinennung, Sebelah Barat Desa Useng Kec. Mare dan Sebelah Selatan Desa Belawae Kec. Mare.

Secara umum Keadaan Topografi Desa Abbumpungeng Adalah daerah dataran dan daerah Pebukitan. Wilyah dusun Pattiro Data berada didaerah perbukitan, sementara dusun Lomping dan dusun Lerang I berada didaerah jalan poros Bone Sinjai dan dusun Lerang II berada di daerah dataran. Iklim Desa Abbumpungeng sebagaimana desa-desa yang lain diwilayah Indonesia beriklim Tropis dengan Dua Musim yakni Musim Kemarau dan Musim Penghujan.

Desa Abbumpungeng terdiri dari 4 dusun yakni Dusun Lomping, Dusun Pattiro Data, Dususn Lerang I dan Dusun Lerang II dengan jumlah Rukun Tetangga (RT) sebanyak 11 buah. Demografi adalah studi ilmiah tentang penduduk, terutama tentang jumlah, sturuktur dan perkembangannya. Berdasarkan hasil sensus peringkat kesejahteraan masyarakat yang dilaksanakan oleh Kader Pemberdayaan Masyarakat (KPM) desa Abbumpungeng, maka diketahui jumlah $761 \mathrm{KK}$ dengan jumlah jiwa 2.575 yang terdiri dari laki-laki 1282 jiwa dan perempuan 1293 jiwa, tingkat pertumbuhan penduduk sudah dapat ditekan dengan masuknya program KB di masyarakat.

Dominan bahasa yang dipakai masyarakat Desa Abbumpungeng kecamatan Cina yaitu bahasa Indonesia sebagai bahasa sehari-sehari khusunya pada kegiatan perekonomian dan sosial, namun pada hubungan keluarga tetaplah digunakan bahasa suku permasingmasing yang bersangkutan seperti suku Bugis, dimana penduduk asli 
Kolaborasi : Jurnal Administrasi Publik, April 2020 Volume 6 Nomor 1

memakai bahasa bugis, sedangkan suku pendatang memakai bahasa suku mereka sendiri.

Desa Abbumpungeng merupakan desa perbatasan antara kecamaan Cina dan Kecamatan Mare maka sebagian dusun di desa Abbumpungeng berada didaerah Jalan Poros yang menghubungkan Kabupaten Bone dengan Kabupaten Sinjai. Tahun 1997 - 2007 bapak Tahir Dumpa Sebagai Kepala Desa Abbumpungeng Pertama beliau menjabat sebagai kepala Desa Selama Dua Periode, Tahun 2007 2017 Dijabat Oleh Bapak Andi Anwar sebagai Kepala Desa Kedua,dengan menjabat selama dua periode sesuai dengan peraturan perundang-undangan yang berlaku serta 2017- Sekarang di Jabat oleh Ir.Andi Pajoppoi sebagai kepala Desa yang menjabat sampai sekarang.

Berikut ini adalah mengenai hasil penelitian yang diperoleh dilapangan baik melalui observasi, wawancara maupun dokumentasi mengenai pengelolaan dana desa di desa Abbumpungeng, Kecamata Cina, Kabupaten Bone.
Pengelolaan dana desa dalam pelaksanaannya untuk mencapai efektifitas serta efisien dalam mencapai tujuan yang telah ditentukan sebelumnya meliputi empat indikator yaitu, perencanaan (planing), pengorganisasian (organizing), pelaksanaan (actuating), dan pengawasan (controlling).

Perencanaan merupakan tahap pertama dalam pengelolaan dana desa, yang dilakukan pada awal tahap perencanaan yaitu melakukan Musdus (musyawarah dusun) di setiap dusun untuk mendengarkan usulan-usulan dari masyarakat disetiap dusun mengenai program apa saja yang akan dilaksanakan untuk tahun yang berlangsung (Permendagri No. 113 tahun 2014). Selain itu, pemerintah desa juga membahas mengenai perencanaan pembangunan desa yang meliputi RPJMDes, RKPDes, yang disusun pada bulan Juli tahun berjalan serta dilaksanakan melalui Musrembangdes. Rancangan RKPDes dilampiri dengan rencana kegiatan dan rencana anggaran biaya (RAB) yang telah diverifikasi (BPKP,2015). Selanjutnya BPD menyelenggarakan Mus- 
Kolaborasi : Jurnal Administrasi Publik, April 2020 Volume 6 Nomor 1

rembangdes yang diperuntukkan untuk membahas dan menyepakati rancangann RKPDes serta membahas prioritas dan skala prioritas program kerja yang akan dilaksanakan.

Adapun hasil wawancara pada beberapa informan di desa Abbumpungeng mengenai tahap perencanaan pada pengelolaan dana Desa adalah sebagai berikut: Hasil wawancara peneliti dengan Sekertaris desa mengenai tahap perencanaan dalam pengelolaan dana desa di desa Abbumpungeng:

"dalam perencanaan itu, sebenarnya ada 3 tahapan yang dilakukan, satu itu melakukan Musdus atau musyawarah dusun setelah itu Musdes dan Musrembang untuk merencanakan apa yang akan dilakukan selama setahun". (wawancara P, tanggal 10 Juni 2019).

Hal ini senada dengan yang dikatakan oleh kepala saksi kesejahteraan dan pelayanan, yang mengatakan bahwa: "dalam perencanaan itu, dalam musyawarah itu semua dipanggil, perangkat desa, BPD, tokoh masyarakat, tokoh agama itu semua terlibat, tokoh wanita semua dilibatkan. Dalam perencanaan itu ada namanya Musdus, ada Musdes, ada Musrembang. Jadi itu kalo Musdus biasanya dilakukan didusun-dusun nanti disetiap dusun itu dia musyawarah apa-apa yang mau dilakukan didusunnya, seperti itu. Setelah itu dilakukan lagi Musdes di desa, setelah Musdes itu ada juga namanya Musrembang. Kalo ini musrembang yang paling utama itu dibahas itu masalah prioritas yang tidak bisa dikerjakan oleh desa maka di usulkan di tingkat kabupaten, itu kalo musrembang dan itu dimulai pada bulan 7 itu sebenarnya orang sudah Musdus terus dilanjutkan sampai bulan 8 orang bisa Musdes sampai bulan 9 karena diakhir bulan 9, orang harus melakukan penetapan RKP”. (wawancara $\mathrm{R}$, tanggal 10 Juni 2019).

Hal tersebut sedikit berbeda dengan yang diutarakan oleh Kepala Dusun Lomping yang mengatakan bahwa: "saya didusun saya ini tidak mengadakan Musdus tetapi saya langsung yang pergi mewakili dusun saya ketika diadakan Musdes, jadi saya hanya mengamati dusun saya, apa-apa yang kurang serta apa yang 
Kolaborasi : Jurnal Administrasi Publik, April 2020 Volume 6 Nomor 1

dibutuhkan didusun saya ini dan saya hanya sampai Musdes dan tidak ikut pada Musrembang karena ada yang lebih tau dari pada saya”. (wawancara $\mathrm{H}$, tanggal 11 Juni 2019).

Namun lain halnya dengan hasil wawancara dengan Kepala Dusun Lerang I yang mengatakan bahwa: "iye, disini kami mengadakan dulu Musdus, jadi dipanggil dulu sebagian masyarakat Dusun Lerang I baru ditanyakan apa pendapatnya atau apa-apa yang menurut masyarakat harus diperbaiki atau dibangun di Dusun Lerang I ini, baru kemudian saya selaku Kepala Dusun menyampaikan pendapat dari warga Dusun saya di Musdes untuk ditindak lanjuti, begitu". (wawancara S, tanggal 11 Juni 2019).

Adapun hasil wawancara dengan masyarakat Dusun Lerang I yang mengatakan bahwa: "iye, kami itu biasanya dipanggil ke rumah Kepala Dusun Lerang I untuk ditanya-tanya tentang kekurangannya Dusunta baru disitu ada semua seperti warga yang tau semua tentang dusun ini jadi bisa menyarankan apa yang dibutuhkan untuk dibangun atau ditambah mungkin". (wawancara M, tanggal 11 Juni 2019).

Dari hasil wawancara diatas, pemerintah desa Abbumpungeng belum maksimal dalam hal perencanaan terbukti dari hasil wawancara di 3 Dusun yang tidak mengadakan Musdus terlebih dahulu dan kurangnya informasi sehingga hal tersebut terjadi yang mengakibatkan banyak masyarakat yang tidak bisa menyampaikan pendapatnya mengenai pembangunan yang dibutuhkan di Dusun mereka

Pembagian kerja atau pengorganisasian merupakan tahap ke tiga dalam pengelolaan dana desa yang mengatur dan menentukan pekerjaan yang telah di sahkan dalam perencanaan tadi sesuai dengan keahliannya. Suatu rencana yang telah dirumuskan dan ditetapkan sebagai hasil penyelenggaraan fungsi perencanaan, dilaksanakan oleh sekelompok orangyang tergabung dalam satuan-satuan kerja tertentu. Penempatan fungsi pengorganisasian segera setelah perencanaan merupa- 
Kolaborasi : Jurnal Administrasi Publik, April 2020 Volume 6 Nomor 1

kan hal yang logis karena suatu rencana yang telah tersusun dengan rapih dan ditetapkan berdasarkan berbagai macam pertimbangan, tidak dapat terlaksana dengan sendirinya. Artinya, adanya rencana tidak dengan sendirinya mendekatkan organisasi dengan tujuan yang ingin dicapainya. Diperlukan berbagai pengaturan yang menetapkan bukan saja wadah tempat dimana berbagai kegiatan itu akan diselenggarakan, tetapi juga tata krama yang harus ditaati oleh setiap orang dalam organisasi dalam interaksinya dengan orang-orang lain, baik dalam satu satuan kerja tertentu maupun antar kelompok yang ada.

Adapun hasil wawancara pada beberapa informan di desa Abbumpungeng mengenai tahap pengorganisasian pada pengelolaan dana Desa adalah sebagai berikut: Hasil wawancara peneliti dengan Sekertaris desa mengenai tahap pengorganisasian dalam pengelolaan dana desa di desa Abbumpungeng: "sebenarnya itu pembagian kerjanya semua itu sudah diatur dalam perencanaan dek, siapa yang akan mengerjakan seperti pembangunan desa itu ada semuami di perencanaan dan kalau di desa ini itu biasanya desa sendiri yang kelola kalau ada pembangunan jadi biar masyarakat kalau bisa mengerjakan suatu pembangunan misalnya selokan atau drenase itu bisa dikerjakan oleh masyarakat kalau memang dia mampu dan jelas diberikan upah untuk itu." (wawancara P, tanggal 10 Juni 2019).

Demikian halnya denga hasil wawancara dengan kepala saksi kesejahteraan dan pelayanan, yang mengatakan bahwa: "di Desa ini,ada memang dibentuk yang namanya TPK (tim pelaksana kegiatan) yang diketuai oleh Masri dan di Desa ini juga menerapkan system swa kelola, tidak di pihak ketigakan artinya masyarakat setempat yang mengerjakan, artinya orang-orang disitu yang bisa mengerjakan pekerjaan yang telah direncanakan sebelumnya, misalnya tukang atau siapa saja yang pandai artinya ahli dibidang tersebut itulah yang dipekerjakan. Semua orang yang mau bekerja serta mampu atau ahli dalam bidang tersebut yah bisa 
Kolaborasi : Jurnal Administrasi Publik, April 2020 Volume 6 Nomor 1

mengerjakannya." (wawancara R, pelaksanaan pada pengelolaan dana tanggal 10 Juni 2019).

Dari hasil wawancara diatas, pemerintah desa Abbumpungeng sangat maksimal dalam tahap pengorganisasian karena memiliki system swa kelola yang melibatkan masyarakat desa Abbumpungeng itu sendiri dalam pembangunan desa, dan itu bagus untuk masyarakat Karena dapat menambah penghasilan serta masyarakat dapat sejahtera.

Pelaksanaan dapat didefinisikan sebagai keseluruhan usaha, cara, teknik, dan metode untuk mendorong para anggota organisasi agar mau dan ikhlas bekerja dengan sebaik mungkin demi tercapainya tujuan organisasidengan efisien, efektif dan ekonomis. Manusia merupakan unsur terpenting dari seluruh unsur administrasi dan manajemen dan fungsi penggerakan merupakan fungsi manajerial yang teramat penting karena secara langsung berkaitan dengan manusia dengan segala jenis kepentingan dan kebutuhannya.

Adapun hasil wawancara pada beberapa informan di desa Abbumpungeng mengenai tahap Desa adalah sebagai berikut: Hasil wawancara peneliti dengan kepala saksi kesejahteraan dan pelayanan mengenai tahap pelaksanaan dalam pengelolaan dana desa di desa Abbumpungeng: "pelaksanaan program kerja di Desa Abbumpungeng ini ada di pemberdayaan ada juga di pembangunan infrastruktur dan juga peningkatan pelayanan kesehatan. Kalau infrastruktur kebanyakan kita di jalan yaitu dalam bentuk talur atau drainase itu di tahun 2017 ada juga irigasi, ada juga jalan tani, jalan pemukiman. Kalau dipemberdayaan itu kita ada pemberian pelatihan serta untuk peningkatan pelayanan kesehatan itu palingan kita memenuhi kebutuhan bidan Desa, Pustu, Posyandu”. (wawancara R, tanggal 10 Juni 2019).

Kepala saksi kesejahteraan dan pelayanan juga menyatakan bahwa waktu yang dibutuhkan dari mulai perencanaan hingga pelaksanaan itu 1 tahun: “....sampai selesai pelaksanaan itu 1 tahun karena perencanaan kan ditahun sebelumnya, sebelum tahun berjalan itu 
Kolaborasi : Jurnal Administrasi Publik, April 2020 Volume 6 Nomor 1

anggaplah misalnya ditahun ini 2019 sebenarnya itu di tahun 2018 sudah selesai perencanaan mulai dari RKP sampai APBDes karena secara aturan itu RKP ditetapkan sampai pertanggal 30 September 2018 jadi di bulan yang sebelum tahun dilaksanakannya dan setelah itu karna da RKP ada turunannya dan turunannya itu APBDes dan sebelumnya penetapannya ini per akhir tanggal 30 September jadi pada Januari 2019 sampai akhir tahun itu bentuk pelaksanaan." (wawancara R, tanggal 10 Juni 2019)

Dalam pelaksanaan program kerja tersebut pun tak luput dari berbagai kendala lanjut dari yang dikatakan oleh kepala saksi kesejahteraan dan pelayanan desa Abbumpungeng sebagai berikut: "saya akui pelaksanaan pembangunan di Desa Abbumpungeng ini belum maksimal $100 \%$ karena ada berbagai kendala yang dihadapi seperti misalnya itu biasanya musim yah kalau untuk bangunan itu yang penghambatnya adalah musim hujan sehingga kadang penyelesaiannya terlambat atau kadang mungkin di akhir-akhir tahun kita kerjakan itu pembangunan karena faktor dana juga yang terlambat keluar dikarenakan laporan yang bisanya terlambat yang menyebabkan pekerjaan tersebut menyebrang artinya anggaplah ditahun 2018 kita rencanakan tetapi karena factor cuaca akhirnya menyebrang sampai tahun 2019 pengerjaannya, seperti itu. Tapi di desa kan kita hanya melihat itu bagaimana dana yang di gelontorkan ke desa itu sетиa terbelanja di tahun itu, karena tidak bisa dibelanjakan di tahun berikutnya, artinya dana desa tahun 2018 harus habis di tahun 2018 juga." (wawancara R, tanggal 10 Juni 2019).

Berdasrkan hasil wawancara diatas maka dapat saya simpulkan bahwa dalam tahap pelaksanaan program kerja di Desa Abbumpungeng masih kurang maksimal karena masih banyak yang belum terlaksana karena berbagai faktor seperti dana yang terlambat cair, faktor cuaca dan faktor yang lainnya.

Pengawasan merupakan proses pengamatan dari seluruh kegiatan organisasi guna lebih menjamin bahwa semua pekerjaan 
Kolaborasi : Jurnal Administrasi Publik, April 2020 Volume 6 Nomor 1

yang sedang dilakukan sesuai dengan rencana yang telah ditentukan sebelumnya. Sebagai fungsi organik dari manajemen, pengawasan merupakan salah satu tugas yang mutlak diselenggarakan oleh semua orang yang menduduki jabatan manajerial, mulai dari manajer puncak hingga para manajer rendah yang secara langsung mengadakan kegiatan-kegiatan teknis yang diselenggarakan oleh semua petugas operasional.

Adapun hasil wawancara dengan kepala kesejahteraan dan pelayanan yang mengatakan bahwa: "pengawasannya yaitu, yang pertama ada tim TPK yang mengawasi pelaksanaannya selain itu sebenarnya juga masyarakat yang mengawasi termasuk juga BPD dan memang yang paling utama yaitu masyarakat karena bangunan itu kan untuk masyarakat." (wawancara R, tanggal 10 Juni 2019). Adapun mengenai transparansi dalam proses pengelolaan dana desa di desa Abbumpungeng ini, berikut hasil wawancara dengan sekertaris desa Abbumpungeng: "kalau mengenai ttransparansi saya mengakui memang masih kurang yah karena belum ada papan pemberitahuan atau papan informasi tentang seluruh proses pengelolaan dana desa di desa ini." (wawancara $\mathrm{P}$, tanggal 10 Juni 2019).

Berdasarkan hasil wawancara diatas maka dapat disimpulkan bahwa selain tim yang dibentuk oleh pemerintah desa yaitu tim TPK, dan lembaga-lembaga terkait dalam hal pengawasan masyarakatlah yang paling utama. Dan yang masyarakat pula yang paling berwenang dan mampu untuk mengawasi secara langsung dalam proses pengelolaan dana desa di desa Abbumpungeng ini karena apapun yang dilakukan ataupun dibangun di desa Abbumpungeng ini, guna untuk masyarakat itu sendiri. Serta transparansi yang sangat kurang terbukti dari belum ada papan informasi serta website yang dapat menginformasikan kepada seluruh warga desa Abbumpungeng mengenai seluruh proses pengelolaan dana desa di desa Abbumpungeng.

KESIMPULAN 
Dari mulai perencanaan yang belum maksimal dalam penyelenggaraannya karena belum melibatkan masyarakat secara langsung dari mulai musdus, dan musdes sehingga masyarakat tidak bisa menyampaikan aspirasinya mengenai pembangunan yang dibutuhkan di dusun mereka.

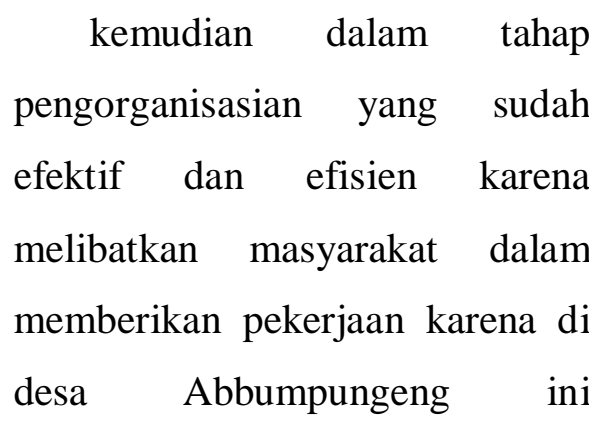
menerapkan system swakelola sehingga pemerintah dapat memberdayakan masyarakat dengan memberikan pekerjaan sesuai dengan kemampuan masyarakat itu sendiri dalam hal pelaksanaan program kerja tadi.

Pada tahap pelaksanaan dapat disimpulkan bahwa dalam pelaksanaan program kerja belum maksimal karena pembangunan disetiap dusun belum merata karena berbagai faktor seperti cuaca dan terlambatnya pencairan dana yang mengakibatkan program kerja yang harusnya terlaksana ditahun berjalan akhirnya dipindahkan ditahun berikutnya.

Dan dalam proses pengawasan sudah efektif karena selain tim TPK, BPD, dan aparat desa, masyarakat juga dilibatkan dalam mengawasi seluruh rangkaina proses pengelolaan dana desa tersebut. tetapi dalam hal transparansi di desa Abbumpungeng sendiri masih sangat belum maksimal karena sama sekali tidak ada papan informasi maupun website yang dapat memberikan informasi kepada seluruh masyarakat mengenai seluruh proses pengelolaan dana desa di desa Abbumpungeng kecamatan Cina kabupaten Bone.

\section{DAFTAR PUSTAKA}

Arikunto, Suharsimi . (1993). Manajemen Penelitian. Jakarta: PT. Raja Grafindo Persada.

Daft L. Richard, 2002. Manajemen, edisi kelima jilid 1, Jakarta, Penerbit Erlangga.

Kasmir, 2006, manajemen sumber daya manusia (teori dan praktek). Jakarta, PT. Raja Grafindo Persada 
Kolaborasi : Jurnal Administrasi Publik, April 2020 Volume 6 Nomor 1

Lapananda, Yusran. (2016). Hukum Pengelolaan Keuangan Desa. Jakarta: Penerbit Graha Pena.

Rahmat, (2017). Manajemen Dana Desa dalam Meningkatkan Pembangunan di Desa Doluduo Kecamatan Dumoga Barat Kabupaten Bolaang Mongondow. E-Jurnal Ilmu Pemerintahan Vol. 2 No. 2 Mei 2019 hlm 3-6

Siagian, S P. (2008). Manajemen Sumber Daya Manusia. Jakarta: PT Bumi Aksara.

Sondang P. Siagian,MPA, 2002, Fungsi-Fungsi Manajerial, Jakarta, Bumi Aksara.PT Indeks

Sugiono, 2016. Metode penelitian (pendekatan kuantitatif, $R \& D$. Bandung: Alfabet

Thomas. 2013. Pengelolaan Alokasi Dana Desa Dalam Upaya Meningkatkan Pembangunan Di Desa Sebawang Kecamatan Sesayap Kabupaten Tana Tidung. Artikel Jurnal, Vol. 1 No. 1.

Terry, G R dan Rue, L W. 2010. Dasar-dasar Manajemen. Cetakan kesebelas. Jakarta: Bumi Aksara.

Undang-Undang Republik Indonesia Nomor 6 Tahun 2014 Tentang Desa Peraturan Pemerintah No 72 tahun 2005.

Peraturan Pemerintah No. 60 Tahun 2014 tentang Dana Desa Yang berasal dari APBN. 12 Juni 2019.

www.djpk.kemenkeu.go.id

$\begin{array}{lr}\text { PerMenKeu } & \text { Nomor } \\ \text { 49/PMK.07/2016 } & \text { mengenai } \\ \text { Tata Cara } & \text { Pengalokasian, } \\ \text { Penyaluran, } & \text { Penggunaan, } \\ \text { Pemantauan } & \text { serta Evaluasi }\end{array}$

Dana Desa. 12 Juni 2019.

www.djpk.kemenkeu.go.id 